\title{
Reference ranges for hemolymph chemistries from Elliptio complanata of North Carolina
}

\author{
Lori L. Gustafson ${ }^{1,2,3,8}$, Michael K. Stoskopf ${ }^{1,3,4}$, William Showers ${ }^{1,5}$, Greg Cope ${ }^{1,4}$, \\ Chris Eads $^{2}$, Richard Linnehan ${ }^{1,3,7}$, Thomas J. Kwak ${ }^{1,6}$, Beth Andersen ${ }^{5}$, \\ Jay F. Levine ${ }^{1,2, *}$
}

${ }^{1}$ Environmental Medicine Consortium, ${ }^{2}$ Population Health and Pathobiology, and ${ }^{3}$ Department of Clinical Sciences; College of Veterinary Medicine, North Carolina State University, Box 8401, North Carolina State University, Raleigh, North Carolina 27606, USA

${ }^{4}$ Department of Environmental and Molecular Toxicology, Box 7633, College of Agriculture and Life Sciences, ${ }^{5}$ Department of Marine, Earth and Atmospheric Sciences, Box 8208, College of Physical and Mathematical Sciences, and ${ }^{6}$ US Geological Survey, North Carolina Cooperative Fish and Wildlife Research Unit, Box 7617, Department of Zoology; North Carolina State University, Raleigh, North Carolina 27695, USA

${ }^{7}$ National Aeronautic and Space Administration, Mail code CB, Lyndon B Johnson Space Center, Houston, Texas 77058, USA

${ }^{8}$ Present address: USDA Animal and Plant Health Inspection Service, 16 Deep Cove Rd, Eastport, Maine 04631, USA

\begin{abstract}
Hemolymph chemistries may be useful nonlethal measures of bivalve health. The prognostic value of hemolymph, however, depends on a comparison of chemistry results to reference ranges from healthy individuals. Currently, knowledge of expected hemolymph values in healthy and unhealthy freshwater mussels is extremely limited. The purpose of this study was to develop a set of reference ranges for clinical evaluation of hemolymph from a freshwater mussel species common to southeastern USA. We collected hemolymph from 380 Elliptio complanata from 19 apparently healthy populations from northwest of Raleigh, North Carolina, during May through July 2001. We present reference ranges for hemolymph parameters ammonia, glucose, calcium, magnesium, phosphorus, aspartate aminotransferase (AST), bicarbonate, protein and cell count, and for tissue glycogen. We compare the subpopulations of mussels from regions with an agricultural riparian buffer to those surrounded predominantly by forested lands. We further present correlations noted between hemolymph chemistries and physical or physiologic parameters. The only statistically significant differences between populations contiguous to agricultural and forested lands were in hemolymph calcium and glucose concentrations. Other statistically significant correlations identified were between gravidity and hemolymph protein concentration and tissue glycogen content, as well as between gravidity and parasite burden, and between shell length and hemolymph glucose, AST, calcium and bicarbonate concentrations. The results of this study will aid the interpretation of health measures from populations of E. complanata of similar geographic and seasonal origin.
\end{abstract}

KEY WORDS: Elliptio complanata $\cdot$ Hemolymph $\cdot$ Hematology $\cdot$ Reference ranges

\section{INTRODUCTION}

Blood samples are routinely used in disease surveillance and diagnosis in companion animal, livestock and human populations, at times providing the first indication of abnormalities (Willard et al. 1994, Feldman et al. 2000, Stockham \& Scott 2002). Hemolymph is the circulatory fluid of freshwater mussels and other invertebrates with open circulatory systems. Collection of hemolymph from freshwater mussels is simple and relatively non-traumatic (Gustafson et al. 2005, this issue). The hemolymph of several marine bivalve species has proven useful in the identification of pathogens and the evaluation of mussel condition 
(Paillard et al. 1996, Allam et al. 2000). Similar assessment strategies based on the nonlethal collection of hemolymph of freshwater bivalves would greatly enhance efforts to conserve and protect endangered and declining populations. However, hemolymph chemistry reference values from healthy freshwater bivalve populations are needed to aid in the interpretation of results.

The development of a hemolymph health assessment protocol for freshwater mussels involves: (1) the establishment of reference ranges from populations of healthy individuals, and (2) the experimental documentation of hemolymph responses to disease or environmental stressors. The latter is conducive to laboratory study and is readily incorporated into physiological studies of bivalve responses to captivity, translocation, toxicant exposure, or disease. Some of this work has already been done. Studies of freshwater bivalves document alterations in hemolymph calcium and glucose subsequent to mussel collection and transport in water-filled containers (Pekkarinen \& Suoranta 1995). Hemolymph magnesium concentrations of zebra mussels Dreissena polymorpha decrease after transport in water-filled containers (Martem'yanov 2000). Emersion (removal from water) times have been correlated with declines in hemolymph $\mathrm{pH}$ in Anodonta grandis (Byrne \& McMahon 1991) and Corbicula fluminea (Byrne et al. 1991), and hemolymph calcium concentrations have been shown to increase when freshwater mussels are exposed to acidified (Pynnonen 1990, 1994) or anoxic waters (Dietz 1974). These studies establish that hemolymph chemistry parameters are affected by conditions that can compromise the health of freshwater mussels. Further research is needed to link hemolymph change to a wider variety of factors that potentially influence freshwater mussel health.

Specifically because of the responsiveness of hemolymph chemistry parameters to subtle environmental factors, the establishment of baseline reference ranges is not readily accomplished through experimental study. Reference ranges are best developed through surveys of relatively large numbers of healthy mussels, from a number of populations, preferably in their natural environment (Solberg 1986, Lumsden \& Jacobs 1989). Broad sampling for reference values helps ensure their applicability to a broad range of subject mussels and populations.

We assembled hemolymph data from 380 wild Elliptio complanata collected from 19 stream reaches in a minimally impacted region of North Carolina over late spring and early summer of 2001 . We present $95 \%$ interpercentile reference ranges from these apparently healthy populations as an initial baseline for clinical interpretation of hemolymph in E. complanata. We compare results between populations contiguous to predominantly forested lands and populations contiguous to more predominant agricultural lands and discuss differences in light of the theory that land use may be a factor governing freshwater mussel declines. In addition, we present correlations of health parameters with general health ratings such as site abundance and diversity rankings, as well as gravidity status and mussel size classification.

\section{MATERIALS AND METHODS}

Site description. Our study centered on a relatively undeveloped region of North Carolina's upper Piedmont northwest of Raleigh, in Orange, Durham and Person counties (Fig. 1). All accessible bridge sites within the Neuse 03-04-01 1 sub-basin, a $1686 \mathrm{~km}^{2}$ region, that were populated with mussels were identified. Land-cover/-use evaluation (1998/99 30 m coverage satellite imagery, Environmental Protection Agency, Washington, DC) indicated that the general character of the sites was very similar in the associated watersheds. Drainage basins upstream of the collection sites were predominantly forested (mean = $61.81 \%, \mathrm{SD}=7.76 \%$ ) with some agricultural influence $($ mean $=30.21 \%, \mathrm{SD}=7.47 \%)$. Sites did show variability, however, in the character of riparian lands immediately contiguous to each surveyed reach. Evaluation of land-cover/-use within $300 \mathrm{~m}$ of each bridge found that a substantial proportion of land adjacent to 9 of the sites was characterized as agricultural (range: 33 to $74 \%$ agricultural, 16 to $58 \%$ forested) compared to the other 10 sites that were surrounded by predominantly forested riparian lands (range: 74 to $98 \%$ forested, $<1$ to $17 \%$ agricultural). Though the aquatic habitat of mussels is influenced by waterborne particulates, toxicants and nutrients from upstream environments, contiguous land-use conditions that affect shading, wind patterns and erosion can also impact communities at a local level. Our sites did not vary greatly in general watershed designations. However, to evaluate potential differences arising from local land-use patterns, we compared health parameters between the sites adjacent to agricultural operations and those adjacent to predominantly forested lands (Fig. 1).

Sites were visited between May 21 and July 12, 2000. A random order for site visits was assigned by a random numbers generator (Microsoft Excel 1998).

\footnotetext{
State designated numerical code for the sub-basin. North California (Division of Water Quality, http:// h2o.enr.state.nc.us/basinwide/Neuse/2002/plan.htm) divides the state's river basins into sub-basins for management purposes
} 


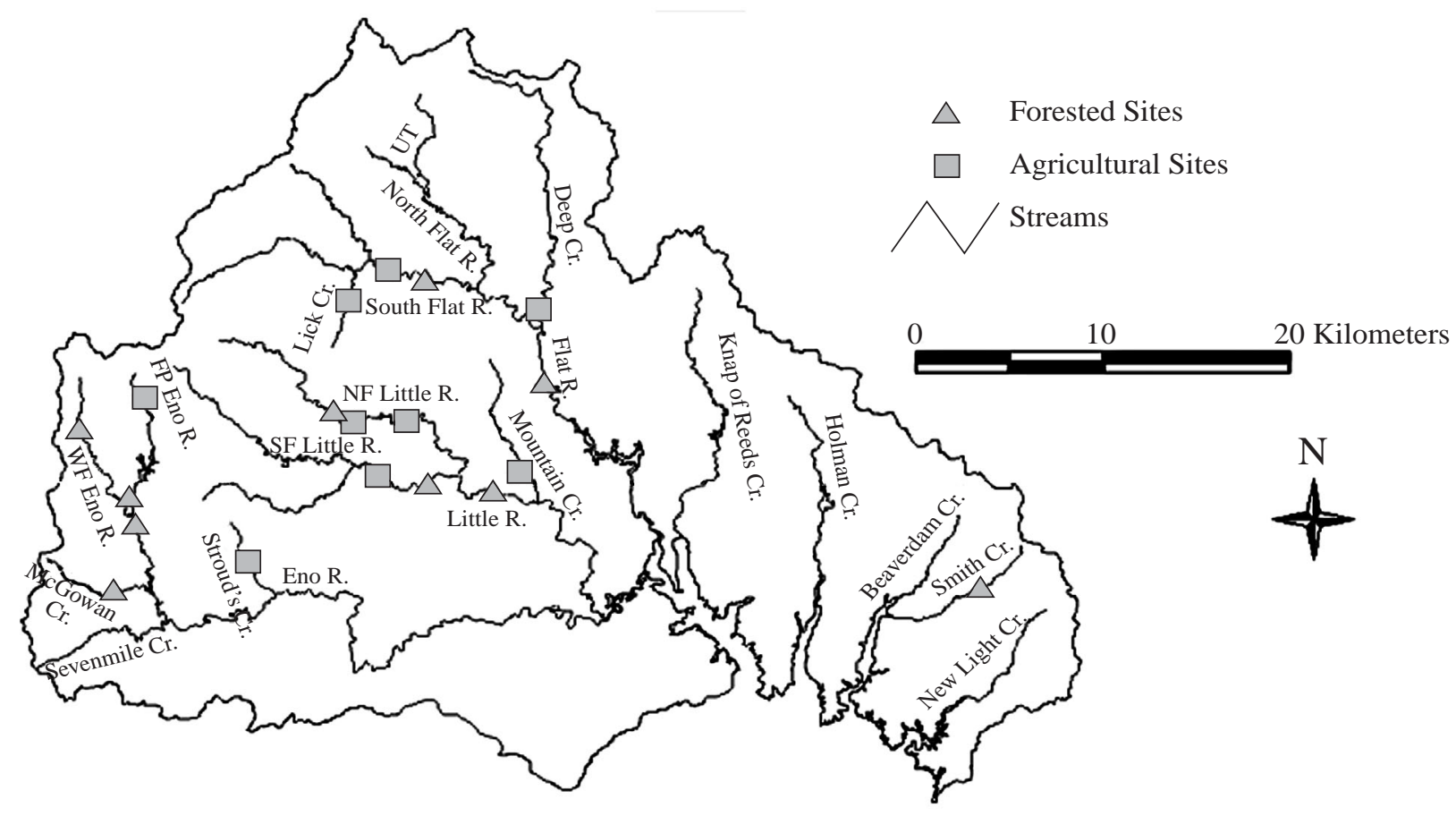

Fig. 1. Neuse river sub-basin 03-04-01늘 in North Carolina and study site locations

Occasionally, however, site visits were postponed when local weather conditions made collection at a particular site impractical. When a site visit was postponed, the next practical site on the randomly ordered list was visited in its place. A $300 \mathrm{~m}$ reach was surveyed above and below each bridge site. Twenty mussels were collected at each site: the first 10 found at least $25 \mathrm{~m}$ upstream of the bridge, and the first 10 found at least $25 \mathrm{~m}$ downstream of the bridge. Only individuals $>40 \mathrm{~mm}$ in length were collected for the study. Study mussels ranged in size from 45 to $98 \mathrm{~mm}$ in length (median $=72$, first quartile $[\mathrm{Q} 1]=65$, third quartile [Q3] = 79) and 9.6 to $129.2 \mathrm{~g}$ in weight (median = 47.33, Q1 = 35.66, Q3 = 63.80), and did not vary significantly in size between forested and agricultural sites, nor between upstream (above the bridge) and downstream (below the bridge) locations.

Relative mussel abundance and diversity were estimated during a concurrent line transect visual survey. Three transects were walked through each stream with glass-bottom buckets and snorkeling gear: transects for each bank, and a transect down the center of the stream. Transects covered $1 \mathrm{~m}$ in width, and all individuals within this range were identified, measured for shell length and counted. The 19 study sites ranged in relative unionid abundance from 64 to 3728 mussels (for the total $600 \mathrm{~m}$ stream reach) and from 1 to 8 unionid species in diversity. For the purposes of this study, sites with relative abundances of
$<200$ unionids and/or only 1 unionid species (Elliptio complanata) were considered low abundance/diversity sites. Five of the 19 sites met this criterion. All other sites were considered substantial in relative unionid abundance and diversity. Relative abundance and diversity data were collected on the same day as the health survey data, along with water quality and land-use characteristics.

Data collection. Mussels were placed in 2 shaded insulated coolers filled with stream water: one designated for upstream water and mussels, the other for downstream water and mussels. They were processed on site as quickly as possible, usually within $2 \mathrm{~h}$ of collection, using a field lab (microscope, centrifuge, and gram scale) powered by an AC adaptor connected to the electrical system of a field vehicle. In 2 instances, power supply failure in the field required the transportation of mussels to North Carolina State University Veterinary College ( 1 to $2 \mathrm{~h}$ driving time) for processing.

During processing, mussels were weighed to the nearest $0.1 \mathrm{~g}$ (Denver XP600 gram scale, Fisher Scientific) and shell dimensions (length, width and height) were measured with Vernier calipers (Fisher Scientific) to the nearest $\mathrm{mm}$. Shell length is a common and robust meristic for field estimation of mussel size (Molina et al. 2001). The other size parameters were collected to estimate mussel weight-tovolume density calculated as mg weight per cubic 
mm (length $\times$ width $\times$ height). Gravidity status was determined visually by inspecting the gills for evidence of inflation and whitish coloration. Between 0.5 and $1.0 \mathrm{cc}$ of hemolymph was collected from the anterior adductor muscle using a 25 ga needle (Gustafson et al. 2005). A Neubauer hemocytometer (Hausser Scientific) was filled with hemolymph and cell count recorded immediately, including all cells in the corner squares of 1 chamber. The remaining hemolymph was centrifuged for $3 \mathrm{~min}$ at $1000 \times \mathrm{g}$, the cellular fraction removed and the supernatant placed in cryovials (Fisher Scientific) on dry ice packed in regular ice for the duration of the field day. Hemolymph was transferred to a $-20^{\circ} \mathrm{C}$ freezer at the end of the day, and analyzed on an automated clinical chemistry analyzer (Hitachi 912, Roche Diagnostics) within $24 \mathrm{~h}$ for colorimetric determination of total protein, aspartate aminotransferase (AST), ammonia, magnesium, calcium, phosphorus and glucose concentrations.

Fourteen of the 20 mussels were returned to the stream after hemolymph collection. The remaining 6 , including the first 3 upstream and the first 3 downstream mussels processed at each site, were sacrificed for histologic evaluation. Tissues were preserved in Davidson's Fixative (Collins 1993) and stained with Hematoxylin and Eosin after routine stepwise tissue dehydration, embedding in paraffin and sectioning to $4 \mu \mathrm{m}$ (Howard \& Smith 1983). Histologic evaluation was used to determine parasite presence and to confirm health status of the study population with standard methods (Chittick et al. 2001). Foot tissue was collected postmortem for glycogen analysis from a convenience sample of the sacrificed mussels from 6 of the forested and 7 of the agricultural sites.

Glycogen analysis followed a modified version of the method used by Patterson et al. (1997), Burton et al. (1997) and Carr \& Neff (1984) in which glycogen is converted to glucose with amyloglucosidase (SigmaAldrich) for glycogen determination. Lyophilized mussel foot samples were weighed on an analytical scale (Mettler AE240, Fisher Scientific) to the nearest $0.1 \mathrm{mg}$. The average dry tissue sample weight was $10.4 \mathrm{mg}$ (range 3.7 to $17.0 \mathrm{mg}$ ). Individual tissue samples were each mixed with 0.5 to $1 \mathrm{ml}$ cold trisodium citrate buffer solution (volume recorded). Tissue samples plus buffer were homogenized with a glass mortar and pestle tissue grinder (Fisher Scientific). The homogenate was distributed into 2 sterile cryovials (Fisher Scientific) in equal volume aliquots, and placed immediately in a boiling water bath for $5 \mathrm{~min}$ (Carr \& Neff 1984). After cooling, $50 \mu \mathrm{l}$ amyloglucosidase solution per $0.5 \mathrm{ml}$ tissue homogenate was added to 1 cryovial of each sample. A total of $50 \mu \mathrm{l}$ of buffer was added to the second cryovial for use as a blank. All samples (and standards and blanks) were incubated in a $55^{\circ} \mathrm{C}$ water bath for $2 \mathrm{~h}$. Samples (and blanks) were centrifuged at $5000 \times g$ (Eppendorf Centrifuge 5413, Fisher Scientific) for $30 \mathrm{~min}$ and the supernatant collected for glucose determination. Glucose concentrations were analyzed using the hexokinase test (Glucose HK Assay Kit, Sigma Diagnostics) at a 1:20 sample to reagent ratio and spectrophotometric absorbances recorded at $340 \mathrm{~nm}$ (Milton-Roy Spectronic 1201). The spectrophotometric absorbance of the tissue minus the blank was compared to the standard glycogen curve to obtain an estimate of tissue glycogen content (mg glycogen $\mathrm{dl}^{-1}$ diluent). The final glycogen concentration was calculated as mg glycogen $\mathrm{dl}^{-1}$ diluent, multiplied by $\mathrm{dl}$ buffer used in the grinding step, divided by $g$ tissue dry weight. Results are reported as mg glycogen $\mathrm{g}^{-1}$ (foot tissue dry weight).

Fresh ice-cold 0.1 M trisodium citrate ( $\mathrm{pH}$ 5.0) buffer solution was used in the preparation of glycogen standards, tissue homogenates and amyloglucosidase $(0.5 \%)$ solution. Glycogen standards were prepared daily by dilution of commerical Mytilus edulis glycogen (Type VII, Sigma-Aldrich) to 10, 50, 100, 150, 200 and $250 \mathrm{mg} \mathrm{dl}^{-1}$. An in-house reference standard was prepared from biopsied Elliptio complanata foot tissues from 15 non-experimental mussels, which were lyophilized and ground to a fine powder with a glass mortar and pestle. The powder was stored at $-20^{\circ} \mathrm{C}$ and homogenates prepared daily as reference standards. Quality control (APHA et al. 1995) included daily measurements of 5 concentrations of glycogen standard, 4 sets of triplicate in-house reference standards, and known additions, and duplicate analysis of $33 \%$ of the tissue samples. Tissue glycogen samples were analyzed in a single batch. The glycogen standard curves for the tissue samples were linear in the test range described (10 to $250 \mathrm{mg} \mathrm{dl}^{-1}$ ) with an $\mathrm{r}^{2}$ (coefficient of determination) value of $99.6 \%$. The average percentage difference of duplicate samples was $12.23 \%$ (range $=1.27$ to 24.36 ). The mean RSD (relative standard deviation) of triplicate in-house standards was $8.13 \%$ (range $=5.44$ to 11.61 ). Recovery of known additions averaged $91.08 \%$ (range $=62.38$ to 109.32).

Statistical analysis. Reference intervals and associated confidence limits for hemolymph parameters were calculated from the group of 380 mussels using nonparametric determination of the central $95 \%$ intervals (Solberg 1986). The nonparametric procedures, based on ranks, alleviated analytical problems associated with data sets bounded by lower limits of detection and allowed out-of-bound data to retain full significance. 
The results for each parameter were sorted in ascending order and assigned a rank number from 1 to n. The bounds of the central $95 \%$ reference interval were then defined as the values corresponding to rank numbers equal to $0.025(n+1)$ and $0.975(n+1)$. If the calculated rank numbers were not integers, then values were interpolated from the 2 closest ranks. The $90 \%$ confidence intervals were calculated from the binomial distribution (Solberg 1986). For datasets of $n$ $=373$ to 380 , the $90 \%$ confidence interval for the lower 2.5 percentile corresponded to rank numbers 5 and 16 . The $90 \%$ CI for the upper 97.5 percentile corresponded to rank numbers $(n+1)-16$ and $(n+1)-5$. For datasets of $\mathrm{n}=364$ to 372 , the $90 \%$ confidence interval for the lower 2.5 percentile corresponded to rank numbers 5 and 15, and the $90 \%$ CI for the upper 97.5 percentile corresponded to rank numbers $(n+1)-15$ and $(n+1)-5$. Out-of-bound data were not an issue for glycogen results, and presumed normality was not rejected by the Kolmogorov-Smirnov test at a 0.05 significance level ( $p>0.15$ ). Consequently, parametric reference ranges, providing narrower distributions, are reported for glycogen.

We used the nonparametric Kruskal-Wallis test (Hollander \& Wolfe 1999) to evaluate differences in health parameter medians between land-use types ( $\mathrm{n}=10$ forested and 9 agricultural sites), and between upstream (above bridge) and downstream (below bridge) collection locations ( $\mathrm{n}=19$ sites). After ruling out statistical dependence between land-use designation and gravidity status or shell length, we used Spearman's Rank correlation coefficient (Hollander \& Wolfe 1999) on the full data set of 380 mussels to identify correlations between mussel length and potential health parameters. We evaluated associations between potential health parameters and gravidity status using logistic regression (Rothman \& Greenland 1998). Associations between site abundance/diversity rank and site prevalence of unusual health measures were established using Chisquare tests (Hollander \& Wolfe 1999) and logistic regression (Rothman \& Greenland 1998).

Bayesian likelihood ratios are presented as measures of strength of association (Rothman \& Greenland 1998) between variables that may hold predictive value for future diagnosis of compromised unionid populations. A Bayesian likelihood ratio represents the prevalence of a characteristic among a compromised (or test) group relative to the prevalence of the same characteristic among the healthy (or control) group (Gustafson et al. 1992, 1998). A likelihood ratio of 1 denotes the lack of a measurable relationship between a particular characteristic and health status. A likelihood ratio $>1$ denotes a predictive (or risk) association between a characteristic and compromised health status. A likelihood ratio $<1$ denotes a protective association (Gustafson et al. 1992, 1998).

\section{RESULTS}

\section{Reference ranges}

Ninety-five percent reference intervals and associated $90 \%$ confidence intervals for meristic parameters and hemolymph chemistries were calculated for the collected Elliptio complanata (Table 1). Animal weights and shell lengths are provided to describe the reference population.

\section{Land-use differences}

There were few differences in the biochemical values of the Elliptio complanata collected near agricultural settings and those residing along forested settings. Only glucose and calcium were significantly different by contiguous land-use designation (Table 2). Glucose values were slightly lower on average in forested settings than in agricultural settings. Calcium

Table 1. Elliptio complanata. Mussel, hemolymph and tissue parameters with 95\% reference (ref.) limits and 90\% confidence intervals for mussels from 19 stream reaches in North Carolina. Weights, lengths and weight-to-volume (density) indices were measured in air on intact animals. A weight-to-volume ratio estimates tissue density. Glucose, phosphorus, calcium, magnesium, aspartate aminotransferase (AST), ammonia, bicarbonate, protein and cell count are hemolymph parameters. Glycogen is a foot tissue parameter

\begin{tabular}{|lccccc|}
\hline Parameter & Mussels & $\begin{array}{c}\text { Lower } \\
\text { ref. limit }\end{array}$ & $\begin{array}{c}\text { Lower limit } \\
90 \% \text { CI }\end{array}$ & $\begin{array}{c}\text { Upper } \\
\text { ref. limit }\end{array}$ & $\begin{array}{c}\text { Upper limit } \\
90 \% \text { CI }\end{array}$ \\
\hline Weight $(\mathrm{g})$ & 380 & 18.8 & $(17.0,21.5)$ & 104.6 & $(96.0,113.3)$ \\
Length $(\mathrm{mm})$ & 380 & 54 & $(52,55)$ & 94 & $(90,95)$ \\
Density $\left(\mathrm{mg} \mathrm{mm} \mathrm{m}^{-3}\right)$ & 380 & 0.58 & $(0.51,0.59)$ & 0.77 & $(0.75,0.79)$ \\
Glucose $\left(\mathrm{mg} \mathrm{dl}^{-1}\right)$ & 372 & $<2$ & $(<2,<2)$ & 4 & $(4,5)$ \\
Phosphorus $\left(\mathrm{mg} \mathrm{dl}^{-1}\right)$ & 374 & $<0.3$ & $(<0.3,<0.3)$ & 0.9 & $(0.9,1.0)$ \\
Calcium $\left(\mathrm{mg} \mathrm{dl}^{-1}\right)$ & 375 & 13.1 & $(12.5,13.8)$ & 23.7 & $(22.7,25.0)$ \\
Magnesium $\left(\mathrm{mg} \mathrm{dl}^{-1}\right)$ & 374 & 1.6 & $(1.5,1.9)$ & 3.8 & $(3.7,4.0)$ \\
AST $\left(\mathrm{U} \mathrm{l}^{-1}\right)$ & 374 & $<4$ & $(<4,<4)$ & 38 & $(27,42)$ \\
Ammonia $\left(\mathrm{mmol}^{-1}\right)$ & 380 & $<10$ & $(<10,<10)$ & 138 & $(111.2,198.8)$ \\
Bicarbonate $\left(\mathrm{mmol} \mathrm{l}^{-1}\right)$ & 375 & $<5$ & $(<5,5)$ & 12 & $(11,13)$ \\
Protein $\left(\mathrm{mg} \mathrm{dl}^{-1}\right)$ & 378 & 19.5 & $(13.3,22.5)$ & 142.8 & $(130.1,160.1)$ \\
Cell count $\left({\left.\mathrm{cells} \mathrm{ll}^{-1}\right)}\right)$ & 377 & 250 & $(170,300)$ & 2300 & $(2020,2900)$ \\
Glycogen $\left(\mathrm{mg} \mathrm{g}^{-1}\right)$ & 78 & 47 & $(36,57)$ & 176 & $(155,187)$ \\
\hline
\end{tabular}


also tended to run slightly lower in mussels from forested streams. The bivalves collected from forested sites were similar in size and weight to those collected from agricultural sites (Table 3).

\section{Spatial and temporal variability}

All parameters varied significantly by stream site (Kruskal-Wallis p-values < 0.05). Therefore, geographic location and/or sampling date appear to play a role in parameter variability. Because the field season was relatively short (May 21 to July 12), little temporal variation was expected. However, individual sites were visited only once, precluding any assessment of temporal variability. None of the health parameters varied in a consistent manner between upstream and downstream collection locations ( $\mathrm{n}=19$ sites, KruskalWallis p-values $>0.05$ ).

\section{Gravidity and shell length}

Hemolymph glucose, AST and alanine aminotransferase (ALT) were negatively correlated with shell length, while hemolymph calcium and bicarbonate showed positive correlations.

Gravidity status was statistically correlated with foot glycogen, hemolymph protein and trematode presence (Table 4). However, only trematode presence showed substantial predictive strength for gravidity status,

Table 2. Elliptio complanata. Differences in median values for health parameters from 19 populations contiguous with forested vs. agricultural settings. Median values represent hemolymph compositions unless otherwise stated. df: degrees of freedom

\begin{tabular}{|c|c|c|c|c|c|c|}
\hline Parameter & $\begin{array}{l}\text { No. of } \\
\text { forested / } \\
\text { agricultural } \\
\text { sites }\end{array}$ & $\begin{array}{l}\text { Forested } \\
\text { site } \\
\text { median }\end{array}$ & $\begin{array}{c}\text { Agricultural } \\
\text { site median }\end{array}$ & $\begin{array}{l}\text { Kruskal- } \\
\text { Wallis } H\end{array}$ & df & $\mathrm{p}$ \\
\hline Glucose $\left(\mathrm{mg} \mathrm{dl}^{-1}\right)$ & $10 / 9$ & $<2$ & $<2$ & 5.28 & 1 & 0.022 \\
\hline Calcium (mg dl-1) & $10 / 9$ & 16.7 & 17.65 & 4.51 & 1 & 0.034 \\
\hline Phosphorus (mg dl ${ }^{-1}$ ) & $10 / 9$ & $0.4 \mathrm{mg} \mathrm{dl}^{-1}$ & 0.5 & 2.77 & 1 & 0.096 \\
\hline Protein $\left(\mathrm{mg} \mathrm{dl}^{-1}\right)$ & $10 / 9$ & 58.83 & 67.05 & 2.16 & 1 & 0.142 \\
\hline Magnesium (mg dl-1) & $10 / 9$ & 2.7 & 2.8 & 1.06 & 1 & 0.303 \\
\hline $\begin{array}{l}\text { Foot tissue } \\
\text { glycogen }\left(\mathrm{mg} \mathrm{g}^{-1}\right)\end{array}$ & $6 / 7$ & 113.9 & 106.5 & 1.00 & 1 & 0.317 \\
\hline Bicarbonate $\left(\mathrm{mmol} \mathrm{l}^{-1}\right)$ & -1) $10 / 9$ & 7.5 & 8.0 & 0.92 & 1 & 0.337 \\
\hline Cell count (cells $\mu \mathrm{l}^{-1}$ ) & $10 / 9$ & 1018 & 1010 & 0.60 & 1 & 0.438 \\
\hline $\operatorname{AST}\left(\mathrm{U} \mathrm{l}^{-1}\right)$ & $10 / 9$ & 5.75 & 6.0 & 0.24 & 1 & 0.622 \\
\hline Shell length (mm) & $10 / 9$ & 71.75 & 71.5 & 0.24 & 1 & 0.624 \\
\hline $\begin{array}{l}\text { Weight-to- } \\
\text { volume }\left(\mathrm{mg} \mathrm{mm}^{-3}\right)\end{array}$ & $10 / 9$ & 0.6766 & 0.6703 & 0.17 & 1 & 0.683 \\
\hline $\begin{array}{l}\text { Parasite } \\
\text { prevalence }\end{array}$ & $10 / 9$ & 0.2977 & 0.4286 & 0.08 & 1 & 0.775 \\
\hline Ammonia $\left(\mu \mathrm{mol} \mathrm{l} \mathrm{l}^{-1}\right)$ & $10 / 9$ & 21.5 & 18.35 & 0.06 & 1 & 0.806 \\
\hline Weight (g) & $10 / 9$ & 47.82 & 47.34 & 0.00 & 1 & 1.000 \\
\hline $\operatorname{ALT}\left(\mathrm{U} \mathrm{l}^{-1}\right)$ & $10 / 9$ & $<4$ & $<4$ & 0.00 & 1 & 1.000 \\
\hline
\end{tabular}

with an odds ratio of 0.25 (Table 4). Adding stream site to the model did not improve its resolution.

Glycogen values were lower in mussels that were gravid (median $=99.61 \mathrm{mg} \mathrm{g}^{-1}$ [dry tissue weight], range $=0-173.60, \mathrm{Q} 1=77.82, \mathrm{Q} 3=125.26)$, relative to those that were not gravid (median $=114.32 \mathrm{mg} \mathrm{g}^{-1}$ [dry tissue weight], range $=57.95-211.07, \mathrm{Q} 1=100.68, \mathrm{Q} 3=$ 138.03), at the time of hemolymph collection. Protein values were slightly higher in mussels that were gravid $\left(\right.$ median $=67 \mathrm{mg} \mathrm{dl}^{-1}$, range $=24.7-174.6, \mathrm{Q} 1=43.38$, $\mathrm{Q} 3=105.27$ ) compared with those that were not gravid $\left(\right.$ median $=55.0 \mathrm{mg} \mathrm{dl}^{-1}$, range $=5.4-159.5, \mathrm{Q} 1=34.6$, Q3 = 73.3). In all, $47 \%$ of the non-parasitized mussels and only $24 \%$ of the parasitized mussels examined were gravid. One of the mussels examined histologically was hermaphroditic: spermatogenic tissue was more common than oogenic tissue, but both were present. This mussel was not gravid.

The percentage of parasitized mussels collected at a site was inversely correlated with the percentage of gravid mussels collected (tremadode percent $=0.485$ to 0.216 gravidity percent; $F=8.82$, regression df $=1$, residual error $\mathrm{df}=17, \mathrm{p}=0.009 ; \mathrm{R}^{2}=34.2 \%$ ). Larval forms of the trematode parasite, possibly Homalometron armatum (Chittick et al. 2001), were found in tissues of $39 \%$ of the mussels studied histologically and $65 \%$ of the sample sites. Trematode parasites were typically found in the foot and mantle tissues of the mussels, though they were also seen in gill, gonad and digestive gland sections. Sections varied in appearance from metacercarial forms encysted within smooth eosinophilic capsules to sporocyst or redia specimens encapsulated within cellular teguments. It was not determined whether these variations in form represent different species or multiple life stages and histologic cross-sections of a single species. Little evidence of host inflammatory response accompanied the parasites, other than possibly a very slight increase in cellular infiltrate in some of the more heavily parasitized specimens. The gonadal tissue of a single mussel was almost entirely obliterated by trematode metacercariae. The host Elliptio complanata had an elevated hematocyte count.

Parasitized mussels were much less likely to be gravid than those that were not parasitized $(\chi=7.594, \mathrm{df}=1$, $\mathrm{p}$-value $=0.006)$. The Bayesian likelihood ratio for parasitized mussels was 2.04 against gravidity. The Bayesian likelihood ratio for parasite-free mussels was 0.66 (or 1/1.52) favoring 
Table 3. Elliptio complanata. Size and weights of 380 individual mussels by contiguous land-use classification

\begin{tabular}{|lccccc|}
\hline Meristic & $\begin{array}{c}\text { Forest } \\
\text { median } \\
(\mathrm{n}=200)\end{array}$ & $\begin{array}{c}\text { Forest 95\% } \\
\text { interpercentile }\end{array}$ & $\begin{array}{c}\text { Agricultural } \\
\text { median } \\
(\mathrm{n}=180)\end{array}$ & $\begin{array}{c}\text { Agricultural } \\
95 \% \\
\text { interpercentile }\end{array}$ & $\begin{array}{c}\text { Kruskal- } \\
\text { Wallis } \\
\text { p-value }\end{array}$ \\
\hline $\begin{array}{l}\text { Weight (g) } \\
\text { Shell length } \\
(\mathrm{mm})\end{array}$ & 76.67 & $(17.5-102.1)$ & 47.77 & $(21.9-104.6)$ & 0.273 \\
$\begin{array}{l}\text { Weight } \\
\text { to volume } \\
\left(\mathrm{mg} \mathrm{mm}^{-3}\right)\end{array}$ & 0.67 & $(0.57-0.76)$ & 0.67 & $(0.58-0.77)$ & 0.777 \\
\hline
\end{tabular}

Table 4. Elliptio complanata. Logistic regression model of trematode status, foot glycogen concentration and hemolymph protein concentration on gravidity status in mussels from 19 stream reaches

\begin{tabular}{|lrlrcccc|}
\hline Predictor & Coefficient & SD & $Z$ & $p$ & $\begin{array}{c}\text { Odds } \\
\text { ratio }\end{array}$ & $\begin{array}{c}\text { Lower } \\
90 \% \text { CI }\end{array}$ & $\begin{array}{c}\text { Upper } \\
90 \% \text { CI }\end{array}$ \\
\hline Constant & 0.988 & 1.148 & 0.86 & 0.389 & & & \\
Trematodes & -1.402 & 0.57 & -2.46 & 0.014 & 0.25 & 0.08 & 0.75 \\
Glycogen & -0.019 & 0.009 & -2.02 & 0.044 & 0.98 & 0.96 & 1.00 \\
Protein & 0.021 & 0.009 & 2.33 & 0.020 & 1.02 & 1.00 & 1.04 \\
\hline
\end{tabular}

gravidity. Parasite prevalence did not correlate with any other individual health parameters.

\section{Mussel abundance and diversity}

Parasitized individuals were more common in low mussel abundance/diversity sites. Similarly, gravid mussels were less prevalent in low abundance/diversity sites. Bayesian likelihood ratios were calculated for each of these parameters as a measure of predictive strength of association. An estimated gravidity prevalence of $35 \%$ or less at the time of sampling was predictive of low abundance and/or diversity ranking for the site (Bayesian likelihood ratio $=1.87$ ). Similarly, an estimated parasite prevalence of $50 \%$ or more was predictive of a low abundance/diversity ranking (Bayesian likelihood ratio $=2.24)$. However, neither association was statistically significant at an alpha level of 0.05 in univariate (chi-square) analysis or in logistic regression analysis.

\section{DISCUSSION}

\section{Reference ranges}

Hemolymph, the circulatory fluid of freshwater mussels, can be obtained without impacting mussel growth or survival (Gustafson et al. 2005). Hemolymph evaluation can offer a nonlethal method of health assessment in threatened and declining populations of
North American unionids provided that baseline reference ranges are established. However, the utility of freshwater mussel hemolymph as a diagnostic tool is dependent on the development of standardized reference ranges that can guide the interpretation of hemolymph compositions. The reference ranges provided in this manuscript are an initial step towards developing hemolymph analysis as a viable diagnostic aid for assessing the health of unionids. The Elliptio complanata used in these studies were obtained from streams in a forested region northwest of Raleigh, North Carolina. By sampling 380 mussels from 19 different populations we have attempted to ensure the reference ranges are relatively robust to site and mussel differences. Histologic examination of a portion of the harvested mussels confirmed the general health of the sampled populations.

We chose to concentrate our efforts on early summer months conducive to our (and others') fieldwork. The current reference ranges are most suited for use on Elliptio complanata collected during early summers in the piedmont region of North Carolina. Bivalve hemolymph parameters are likely to change with species, season, water quality and habitat type (Holopainen 1987, Pekkarinen 1997), and knowledge of the extent and probability of these variations is also essential to appropriate interpretation of this type of data. Results may also vary somewhat with different laboratories, personnel and methods of analysis. The extent and implications of expected differences by season, geography, laboratory and species have not yet been established and need further study.

Our sites were fairly homogenous in measured water quality parameters. Sites were also homogeneous at the level of the watershed. Approximately $70 \%$ of the contributing watershed was classified as forested, and approximately $30 \%$ as agricultural in the vast majority of sites. However, classification of the riparian zone immediately proximate to our collection sites did show more variability, with half of the sites adjacent to predominantly forested settings and half adjacent to mild to moderate agricultural activity (including land designated for crop or animal production, whether active or currently fallow). We found few differences in health parameters relative to adjacent land-use patterns. However, given the current and ongoing declines of many sensitive freshwater mussel species (Bogan 1993), it is important to examine these findings in relation to our expectations regarding land-use. 


\section{Land-use influence}

We observed a significant difference in calcium and glucose values between populations residing along primarily forested versus agricultural riparian tracts. On average, both calcium and glucose were higher near agricultural tracts. Hemolymph glucose is a measure of the carbohydrate energy released and circulating in the bloodstream. Many, if not all, bivalve tissues and organs are capable of breaking down glycogen, the principal storage form of carbohydrate, into glucose (Gabbott 1983). Circulating glucose levels may reflect the bivalve's ability or readiness to respond to immediate nutritional needs. Heightened circulating glucose may be a response to weather extremes, handling stress (Pekkarinen \& Suoranta 1995) or any recent environmental stress perceived to require extra fuel. It is also possible that simple differences in habitat could account for these effects. For example, shading and riparian zones associated with the forested streams may help buffer changes in weather (sun, rain, wind and temperature changes) that seem more intense in the open environment of the agricultural habitats. In this sense, the mussels from agricultural areas may, on average, experience greater fluctuations in environmental condition than their similarly treated forest counterparts.

Calcium is a circulating ion important in shell formation, acid-base regulation and respiratory health (McMahon 1991). Calcium, phosphates, silica and magnesium solutes in streams originate primarily from weathering of soils and rocks (Webster \& Ehrman 1996). Differences in calcium may reflect differences in habitat health. Hemolymph calcium is known to increase in response to anoxic or hypoxic conditions (Pynnonen 1990, 1994). Calcium is exchanged for hydrogen ions, allowing for homeostasis of ionic equilibrium while helping to balance blood $\mathrm{pH}$ (crucial to enzyme regulation and mussel survival) (McMahon 1991). While many of these streams were relatively shallow and apparently well oxygenated, small differences in oxygen availability related to nutrient enrichment might affect calcium values. Siltation, potentially clogging gill membranes or impeding gill function, might also affect oxygenation and result in slight differences in calcium levels, though both hypotheses need experimental confirmation.

\section{Parasite burden, gravidity and mussel size}

We found that trematode prevalence was heaviest in sites with low abundance or low species diversity. Little histologic evidence of inflammation accompanied the parasite burden, however, and hematologic parameters, on average, did not show any statistical relationship to parasite burden. This suggests that the mussels are perhaps fairly well adapted to the parasite, and that different hematological measures are needed to support non-lethal detection. However, in seemingly related correlations, gravidity was less prevalent in parasitized mussels, and also less prevalent in the low abundance/diversity sites. These findings, in concert with observations of mild to severe trematode presence in gonadal tissues, raise the concern that trematode infestation may directly diminish a population's reproductive potential. Alternatively, parasite infestation may be a corollary of, or secondary to, habitat quality (Chittick et al. 2001). Further research to establish the population effects of this relatively common freshwater mussel parasite is recommended.

Mussels that were gravid at the time of collection had significantly lower median glycogen values than the other individuals. This may reflect the energy required to maintain or produce glochidia. Gravid mussels also had significantly higher hemolymph protein values than their non-gravid counterparts. It is possible that the osmoregulatory function of the gill is impacted somewhat by brooding glochidia, affecting hemolymph protein either by compensatory or direct response. It is also possible that the lower protein values correspond to a metabolic shift away from carbohydrates in glycogen- depleted conditions. Given the subtle nature of impacts at our study sites, we recommend that parasite burden, glycogen, gravidity, and hemolymph protein, calcium and glucose receive future attention as possible early warning indicators of habitat demise.

Size, represented by shell length, also showed some statistical association with certain measured parameters. The strengths of these correlations were relatively weak (small correlation coefficients). However, given the relative homogeneity of mussel size in our study, this parameter may be important to future work. Hemolymph glucose, AST and ALT, for example, did show linear dependence on shell length, with the highest values in the smallest mussels. Hemolymph calcium and bicarbonate, in contrast, were positively correlated with shell length, showing the highest values in the largest mussels.

\section{CONCLUSIONS}

We have provided reference ranges for parameters that are measurable nonlethally, and are potentially responsive to disease, in freshwater bivalves. This research serves as an initial foundation for biological interpretation of hemolymph chemistries in the freshwater mussel species Elliptio complanata. The mussels 
chosen for the reference set were collected from apparently healthy populations in relatively undisturbed forested stream reaches in a rural section of North Carolina. The season of collection (21 May to 12 July) corresponded with a period in which many of the mussels were gravid. The collection season was relatively moderate in temperature for the region and ceased before ambient temperatures hit summer highs. The reported hemolymph reference ranges, particularly for cell count, protein, ammonia, glucose, calcium, magnesium, AST and bicarbonate, may help to target populations falling outside expectations for the species and collection season and deserving further diagnostic or research attention. However, continued investigation into the variability of hemolymph composition with season, species and disease is required for hemolymph evaluation to achieve its full utility as a nonlethal aid to health and disease diagnosis in freshwater mussel populations.

Acknowledgements. We thank the North Carlina Department of Transportation for providing funding for this research. We thank J. Johnson and J. Alderman formerly with North Carolina's Wildlife Resources Commission, and T. Savidge formerly with North Carolina's Department of Transportation for guidance and support on field collection protocols. We also thank L. Humphries, H. Boyette, C. Wood and A. Lee for their assistance in sample collection and S. Ballantyne and the Clinical Pathology Laboratory of North Carolina State University College of Veterinary Medicine for conducting hemolymph chemistry analyses. The North Carolina Cooperative Fish and Wildlife Research Unit is jointly supported by North Carolina State University, North Carolina Wildlife Resources Commission, US Geological Survey, and Wildlife Management Institute.

\section{LITERATURE CITED}

Allam B, Paillard C, Howard A, Le Pennec M (2000) Isolation of the pathogen Vibrio tapetis and defense parameters in brown ring diseased Manila clams Ruditapes philippinarum cultivated in England. Dis Aquat Org 41:105-113

APHA (American Public Health Association, American Water Works Association and Water Environmental Federation) (1995) Standard methods for the examination of water and wastewater, 19th edn. APHA, Washington, DC

Bogan AE (1993) Freshwater bivalve extinctions (Mollusca: Unionidae): a search for causes. Am Zool 33:599-609

Burton SA, Mackenzie AL, Davidson TJ, Macnair N (1997) Evaluation of a glucose oxidase/peroxidase method for indirect measurement of glycogen content in marine mussels (Mytilus edulis). J Shellfish Res 16:435-439

Byrne RA, McMahon BR (1991) Acid-base and ionic regulation, during and following emersion, in the freshwater bivalve, Anodonta grandis simpsoniana (Bivalvia: Unionidae). Biol Bull 181:289-297

Byrne RA, Shipman BN, Smatresk NJ, Dietz TH, McMahon RF (1991) Acid-base balance during emergence in the freshwater bivalve Corbicula fluminea. Physiol Zool 64: 748-766

Carr RS, Neff JM (1984) Quantitative semi-automated enzymatic assay for tissue glycogen. Comp Biochem Physiol $77(\mathrm{~B}): 447-449$
Chittick B, Stoskopf M, Law M, Overstreet R, Levine J (2001) Evaluation of potential health risks to Eastern Elliptio (Elliptio complanata) (Mollusca: Bivalvia: Unionida: Unionidae) and implications for sympatric endangered freshwater mussel species. J Aquat Ecosyst Stress Recovery 9:35-42

Collins R (1993) Principles of disease diagnosis. In: Brown L (ed) Aquaculture for veterinarians: fish husbandry and medicine. Pergamon Press, New York, p 69-89

Dietz TH (1974) Body fluid composition and aerial oxygen consumption in the freshwater mussel, Ligumia subrostrata (Say): effects of dehydration and anoxic stress. Biol Bull 147:560-572

Feldman BF, Jinkl JG, Jain JC (2000) Schalm's veterinary hematology, 5th edn. Lippincott Williams and Wilkins, Philadelphia, PA

Gabbott PA (1983) Developmental and seasonal metabolic activities in marine mollusks. In: Hochachka PW (ed) The Mollusca, Vol. 2, Environmental biochemistry and physiology. Academic Press, New York, p 165-217

Gustafson D, Cats-Baril W, Alemi F (1992) Systems to support health policy analysis. Health Administration Press, Ann Arbor, MI

Gustafson LL, Franklin WL, Sarno RJ, Hunter RL, Young KM, Johnson WE, Behl MJ (1998) Predicting early mortality of newborn guanacos by birth mass and hematological parameters: a provisional model. J Wildl Manag 62:24-35

Gustafson LL, Stoskopf MK, Bogan AE, Showers W, Kwak TJ, Hanlon S, Levine JF (2005) Evaluation of a nonlethal technique for hemolymph collection in Elliptio complanata, a freshwater bivalve (Mollusca: Unionidae). Dis Aquat Org 65:159-165

Hollander M, Wolfe DA (1999) Nonparametric statistical methods, 2nd edn. John Wiley \& Sons, New York

Holopainen IJ (1987) Seasonal variation of survival time in anoxic water and the glycogen content of Sphaerium corneum and Pisidium amnicum (Bivalvia, Pisidiidae). Am Malacol Bull 5:41-48

Howard DW, Smith CS (1983) Histological techniques for marine bivalve molluscs. NOAA Tech Mem NMFSF/NEC-25. US Department of Commerce, NOAA, National Marine Fisheries Service, Woods Hole, MA

Lumsden JH, Jacobs RM (1989) Clinical chemistry. Vet Clinics N Am Small Anim Practice 19:875-898

Martem'yanov (2000) The dynamics of the sodium, potassium, calcium, magnesium contents in the fresh water mollusc zebra mussel Dreissenia polymorpha during stress. J Evol Biochem Physiol 36:41-46

McMahon RF (1991) Mollusca: bivalvia. In: Ecology and classification of North American freshwater invertebrates. Academic Press, New York, p 315-399

Molina RA, Levine JF, Hanlon SD, Savidge T, Bogan AE (2001) A method for measuring growth in living freshwater mussels. Abstract 2nd Symp Freshw Mussel Conserv Soc, 12-14 March 2001, Pittsburg, PA

Paillard C, Ashton-Alcox KA, Ford SE (1996) Changes in bacterial densities and hemocyte parameters in eastern oysters, Crassostrea virginica, affected by juvenile oyster disease. Aquat Living Resour 9:145-158

Patterson MA, Parker BC, Neves RJ (1997) Effects of quarantine times on glycogen levels of native freshwater mussels (Bivalvia: Unionidae) previously infested with zebra mussels. Am Malacol Bull 14:75-79

Pekkarinen M (1997) Seasonal changes in calcium and glucose concentrations in different body fluids of Anodonta anatina (L) (Bivalvia: Unionidae). Neth J Zool 47:31-45

Pekkarinen M, Suoranta R (1995) Effects of transportation stress and recovery and sample treatment on calcium and 
glucose concentrations in body fluids of Anodonta anatina (L). J Shellfish Res 14:425-433

Pynnonen K (1990) Physiological responses to severe acid stress in four species of freshwater clams (Unionidae). Arch Environ Contam Toxicol 19:471-478

Pynnonen K (1994) Hemolymph gases, acid-base status, and electrolyte concentration in the freshwater clams Anodonta anatina and Unio tumidus during exposure to and recovery from acidic conditions. Physiol Zool 67:1544-1559

Rothman KJ, Greenland S (1998) Modern epidemiology, 2nd edn. Lippincott-Raven Publishers, Philadelphia, PA, p 183-189

Editorial responsibility: Albert K. Sparks, Seattle, Washington, USA
Solberg HE (1986) Establishment and use of reference values. In: Tietz NW (ed) Textbook of clinical chemistry. WB Saunders, Philadelphia, PA, p 356-386

Stockham SL, Scott MA (2002) Fundamentals of veterinary clinical pathology. Iowa State Press, Ames, IA

Webster JR, Ehrman TP (1996) Solute dynamics. In: Hauer FR, Lamberti GA (eds) Methods in stream ecology. Academic Press, San Diego, CA, p 145-160

Willard MD, Tvedten H, Turnwald GH (1994) Small animal clinical diagnosis by laboratory methods, 2nd edn. WB Saunders, Philadelphia, PA

Submitted: April 28, 2004; Accepted: January 4, 2005 Proofs received from author(s): June 28, 2005 